\title{
Students' awareness and use of Information Communication Technology in the Walton Whaley Library of the Valley View University in Ghana
}

\author{
Samuel Ameyaw \\ Valley View University (VVU), Oyibi - Accra \\ George Tesilimi Banji \\ University of Health and Allied Sciences, PMB 31. Ho \\ Frank Afoakwa Boateng \\ Presbyterian University College (PUCG), Asante Akyem Campus. Ghana
}

\begin{abstract}
Information Communication Technology has increasingly become very important in our daily lives and also in our Ghanaian educational system. Realising the positive effect of ICT in the educational system and most importantly in the navigation of library resources, this study sought to investigate the awareness and use of ICT in the Walton Whaley Library (WWL) of the Valley View University (VVU) in Ghana. The study employed the quantitative approach and used questionnaire to collect data from a total a sample of two hundred and twenty-six (226) students using the simple random sampling technique. The study revealed that majority of the students were aware and accessed the various ICT facilities in the library under investigation. The study also discovered that photocopiers, internet and computer services were highly patronised. However, CD-ROMs and scanning services of the library were least patronised. The study recommended that although, the respondents were aware of the ICT facilities available in the library, management should intensify the awareness creation for all students through library orientations, user education as well as seminars and workshops. Lastly, students who want to pursue higher education must endeavor to acquire ICT skills.
\end{abstract}

Keywords: Students; Awareness; Use; Information Communication Technology; Walton Whaley; Library; Valley View University; Ghana.

DOI: $10.7176 / \mathrm{IKM} / 9-3-05$

Publication date:March $31^{\text {st }} 2019$

\section{Introduction}

The introduction and adoption of Information and Communication Technology (ICT) in academic institutions has brought about the computerization of print resources such as books, journals newspaper as well as other materials in the library. This has also given birth to the virtual library where users can access a myriad of information at a click of a computer button regardless of their geographical location (Olise, 2010). Subsequently, the introduction of information and communication technology (ICT) into academic libraries in the $21^{\text {st }}$ century has tremendously brought some drastic changes in the service delivery functions of libraries.

According to Qutab, Bhatti and Ullah (2014), ICT could be considered as a combination of interconnected hardware and software with fringe equipment that is programmed for convenience information exchange. This means that ICT is the umbrella term that encompasses communication devices which include radio, television, cellular phones, computers, networks, hardware, software and satellite systems (Asiamah, 2011).

Globally, university libraries are now moving from the traditional method of providing information to ICT based services which facilitates learning and research as well as attaining access to varieties of information without wasting the precious time of users (Ifinedo, 2006). This therefore means that the use of ICT in academic libraries has gone a very long way to reduce the burdens and challenges that users face when searching for information in the libraries. Additionally, the acceptance and use of ICT in the academic library will not only contribute to the achievement of the library's mission and goals but to the realisation of the aims and vision of the entire university and the nation as a whole.

Adedeji (2010) opined that ICT had been an effective tool for attaining social, economic, political, educational, scientific and technological development. ICT in all sectors of education as a learning instrument 
has made students-centered and self-directed learning, since ICT expedites the acquisition of knowledge (Fu, 2013).

Many studies have been conducted on ICT usage in academic libraries worldwide. However, little work has been done on the use of ICT in private university libraries. Hence, this study has been carried out to fill this intellectual gap on issues of private universities and the purpose is to contribute knowledge to the existing literature in the area of ICT in libraries in Ghana and beyond.

\section{Problem statement}

Previously, services provided by academic libraries were done manually and this consumed a lot of time for the expectations and aspirations of patrons to be met. In this regard, the adoption of ICT in the service delivery functions of academic libraries today have opened another chapter for new development in library services. This rapid growth and advancement of ICT have made users' needs and requests complex, and has also compelled library staff to acquire the requisite and adequate skills to deliver a swift and timely services to patrons.

Ezeani (2010) notes that knowledge of computer and its application will no doubt revitalize service delivery functions of libraries to patrons. It is against this reason that the university authority and library management have put their limited resources together and invested heavily in the purchasing and acquisition of ICT facilities to enhance learning and research in the library.

Pathetically, preliminary observations by the researcher have revealed that the use of these facilities by students is below what one is expected. Additionally, Ibrahim, Asiedu and Aikins (2017) have carried similar studies on ICT usage in academic libraries in various public university libraries in Ghana. Regrettably, there is no similar study carried out in Walton Whaley Library (WWL) of the Valley View University. It is against this backdrop that this study has sought to examine the awareness and use of ICT among students of Valley View University in Ghana.

\section{Research questions}

The study answered the following research questions:

- Are the students' aware of ICT facilities in the Walton Whaley Library of the Valley View University in Ghana?

- Do students have access to the ICT facilities in the Walton Whaley Library?

- What is the frequency of use of ICT facilities in the Walton Whaley Library in the Valley View?

\section{Literature review}

\subsection{Awareness of Information Communication Technology facilities in the Library system}

Awareness of library resources by users is one of the key components that encourage patrons to access the information that a particular library holds. Saini, Bhakar, and Singh (2014) did a study on user satisfaction of the students of Engineering College Libraries of Jaipur, Rajasthan. The findings of their study revealed that majority of the students (58\%) were aware of the information and communication technology (ICT) services in the library and had expressed their satisfaction on the services, however, $(62 \%)$ were not satisfied with the facilities of online database, while $(8 \%)$ of the respondents indicated full satisfied with the availability of databases, and others were partially satisfied with online public access catalogue (OPAC).

Ajuwon (2003) also conducted a study on the adoption of ICT by health science students at the University College Hospital, Ibadan. The findings revealed that students could not use computers, resulting to low use of databases because of lack of awareness, lack of access to computers as well as inadequate training and the high cost of provision of electronic resources.

Similarly, Chirra and Madhusudhan (2009) conducted a study on the use of e-journals by doctoral students of Goa University, India, and reported that students were aware of the presence of e-journals of the Consortium and also accessed them. On the contrary, Manda (2005) also established that PERI resources in academic and research institutions in Tanzania were under-utilized due to the lack of awareness of these resources coupled with inadequate publicity on them. Ojo and Akande (2005) in a related study at the University College Hospital (UCH) of Ibadan discovered that students' awareness of online information resources, level of access, and usage was not encouraging. The study also discovered that one of the challenges confronting users was inadequate knowledge on how to search information online. And this has resulted in poor usage of resources by medical students in the university understudied. 
In addition, Wijetunge (2015) conducted a study on information resources usage of the undergraduate students offering agriculture science at the University of Peradeniya, Sri Lank and the result indicated that a significant number of students were not aware of the online public access catalogue and the e-resources provided via the library's webpages. In a related study by Namugera (2014) on users' awareness, perceptions and usage of Makerere library services in the main and selected branches of the library highlighted that the level of awareness of some library services was discouraging.

\subsection{Accessibility of Information Communication Technology facilities in the Library system}

Access to Information Communication Technology (ICT) services and benefits for the developing countries is not only imperative but also a great challenge from the various viewpoints as poverty, lack of digital education, infrastructure, and stable political environment are becoming the key barriers (Poudel, 2010). Egberongbe (2011) buttressed that by indicating that e-resources are available in the University of Lagos library and that students have access to them and used them heavily for their learning purposes.

In a similar study by Akintunde (2006), he discovered that there were databases such as Agora, Hinari, Oare, Medline, Jstor, and Oxford University Press Journal available at the University of Jos library and students access them free. According to Dike (2005) instant access to information from various sources is one of the core reasons for ICT application in modern academic library services. The use of ICT in the university library is not only to help retrieval of information but also to aid users to sort out significant information from irrelevant information. Subsequently, Anyira (2011) on internet services in Nigerian private universities revealed that out of the 240 respondents, about $100(41.7 \%)$ of the respondents admitted that the internet is slightly accessible, followed by another set of 100 representing $41.7 \%$ also indicated that the internet is not accessible to them. On the other hand, about $30(12.5 \%)$ of the respondents agreed that the internet is very accessible to them whereas $10(4.1 \%)$ of the respondents indicated that it was not accessible at all.

\subsection{Frequency of use of Information Communication Technology facilities in the search of resources in the Library}

Several studies were conducted to establish various degrees of understanding on the frequency of use of ICT facilities in the search of resources in the library system. One of such studies was the study conducted by Kumarjit and Lal Vishwakarma (2005) on the use of library resources by students of Assam University. This study revealed that out of the total of 105 respondents, 37 (35.23\%) of the respondents indicated that they visited the library every day, and about $23(21.90 \%)$ of the respondents also occasionally visited the library whereas 13 $(12.38 \%)$ indicated that they visited the library once in a week. The study also added that majority of the respondents preferred electronic resources as compared to print resources.

Jagboro (2003) also carried out a similar study on ICT utilization at the Obafemi Awolowo University, Nigeria. His findings established that $22.1 \%$ of the respondents accessed the internet on a daily basis, whereas $38.2 \%$ of the respondents accessed the facilities on a weekly basis. About $11.8 \%$ and $16.2 \%$ of the respondents used the facilities on monthly and quarterly basis respectively. Kaur and Mahajan (2012) affirmed in their study on libraries of seven institutes of North India and established that out of 132 respondents used for the study, 82\% visited the library frequently, followed by $6 \%$ who indicated they never visited the library at all. It was also established that $70 \%$ of the respondents visited the library just to check on the availability of documents they needed.

Similarly, Idiegbevan-Ose and Ugwunwa (2013) hinted that out of 473 respondents, $68.1 \%$ of the respondents indicated that they visit the library very often, while $31.9 \%$ of the respondents said they visit the library sometimes. According to the study, 96.4\% respondents were satisfied with the collection of textbooks followed by $89.3 \%$ respondents who were pleased with library staff, however, $34 \%$ of the respondents were dissatisfied with the photocopy and printing services in the library.

Saini, Bhakar, and Singh (2014) did a related study at Engineering Colleges in Rajasthan. The findings reported that out of 200 respondents, $30 \%$ of the respondents visit the library every day while $53 \%$ visited the library once a week. It was also revealed that $95 \%$ of the respondents visited the library for books only whereas $25 \%$ visited the library to read newspapers. Mohindra and Kumar (2015) also undertook similar study to explore user satisfaction regarding the quality of library services of AC Joshi Library, Panjab University, Chandigarh. The results indicated that out of 220 respondents, $127(57.72 \%)$ visited the library on daily, followed by $20 \%$ who visit the library few times in a week. Nkamnebe, Udem and Nkamnebe (2014) on use of library resources and services by students of Paul University, Akwa in Anambra State, Nigeria, established that the use of library services by students on a daily basis was not encouraging.

Conclusively, Omotayo (2010)'s study on the use of electronic journals also discovered that $22(8.98 \%)$ respondents use electronic journals daily, followed by 67 (37.35\%) of the respondents used them weekly. About $102(41.63 \%)$ of the respondents also indicated that they used them bi-monthly while $13.88 \%$ and $8.16 \%$ used 
electronic journals monthly and occasionally respectively. From this study's discovery, it is obvious that various categories of students make use of electronic resource in diverse ways.

\section{Methodology}

The methodology used for this study includes research design, population, sample size, sampling techniques, instrumentation, and how data collected was analysed and interpreted.

The design used for the study was survey research design. The target population for the study was the undergraduate students of the Valley University, Oyibi Campus. The total population for the students at the time of conducting this study was two thousand, two hundred and seventy-three $(2,273)$. Two hundred and twenty-six (226) students were sampled for the study using the simple random sampling technique. Data was collected using structured questionnaire. Out of the 226 copies of questionnaires distributed, 215 was retrieved giving about $95.13 \%$ response rate. The Statistical Package for Social Sciences (SPSS) version 20.0 was used to analyse the data collected. Frequencies tables and histogram were used to present the interpretation.

\section{Results and discussion}

\subsection{Availability of Information Communication Technology facilities in the library}

Table 1 presents respondents' view on the availability of information communication technology (ICT) facilities in the library under investigation.

\begin{tabular}{|c|c|c|c|c|c|c|}
\hline \multirow{2}{*}{ ICT Facilities } & \multicolumn{2}{|l|}{ Agree } & \multicolumn{2}{|l|}{ Neutral } & \multicolumn{2}{|l|}{ Disagree } \\
\hline & Frequency & Percentage (\%) & Frequency & Percentage (\%) & Frequency & $\begin{array}{l}\text { Percentag } \\
\text { e }(\%)\end{array}$ \\
\hline Adequate Computers & 198 & $(92.09 \%)$ & 3 & $(1.4 \%)$ & 14 & $(6.51 \%)$ \\
\hline Internet Services & 213 & $(99.07 \%)$ & 12 & $(5.58 \%)$ & - & - \\
\hline Printing Services & 57 & $(26.51 \%)$ & 15 & $(6.98 \%)$ & 143 & $(66.51 \%)$ \\
\hline Scanning Services & 17 & $(7.90 \%)$ & 35 & $(16.28 \%)$ & 163 & $(75.81 \%)$ \\
\hline Photocopy Services & 211 & $(98.14 \%)$ & 4 & $(1.86 \%)$ & - & - \\
\hline CD-ROMs & 2 & $(0.93 \%)$ & & & 203 & $(94.42 \%)$ \\
\hline Wireless Access Point & 194 & $(90.23 \%)$ & 16 & $(7.44 \%)$ & 5 & $(2.33 \%)$ \\
\hline
\end{tabular}

Source: Field data, 2019

From Table 1, when the respondents were asked about the availability of information communication technology facilities in their library, out of a total of 215 respondents 198 representing $92.09 \%$ agreed that there are adequate computers in the library however, $6.51 \%$ disagreed with the statement. The findings also revealed that majority of $99.07 \%$ agreed that there are internet services in the library, whereas only $5.58 \%$ of the respondents remained neutral to the statement. On the other hand, $211(98.14 \%)$ of the respondents agreed that there were photocopy services in the library while $1.86 \%$ remained neutral to the statement. Again, the researcher sought the views of the respondents to find out whether there were printing services in the library and $66.51 \%$ disagreed. However, 26.51\% agreed that there were printing services in the library, and 6.98\% remained neutral. Surprisingly, a significant number of 203 representing $94.42 \%$ of the respondents disagreed that CD-ROMs are not available in the library but $0.93 \%$ of the respondents agreed. The finding of this study is in contrast with that of Ekenna and Iyabo (2013)'s finding that students patronised CD-ROMs more than any other e-resources in the library.

\subsection{Students' Awareness of Information Communication Technology facilities in the library}

Figure 1 presents respondents' view on their awareness of the availability of ICT (Information Communication Technology) facilities in the library under investigation. The views were presented as below. 
Figure 1: Students' awareness of Information Communication Technology facilities in the library

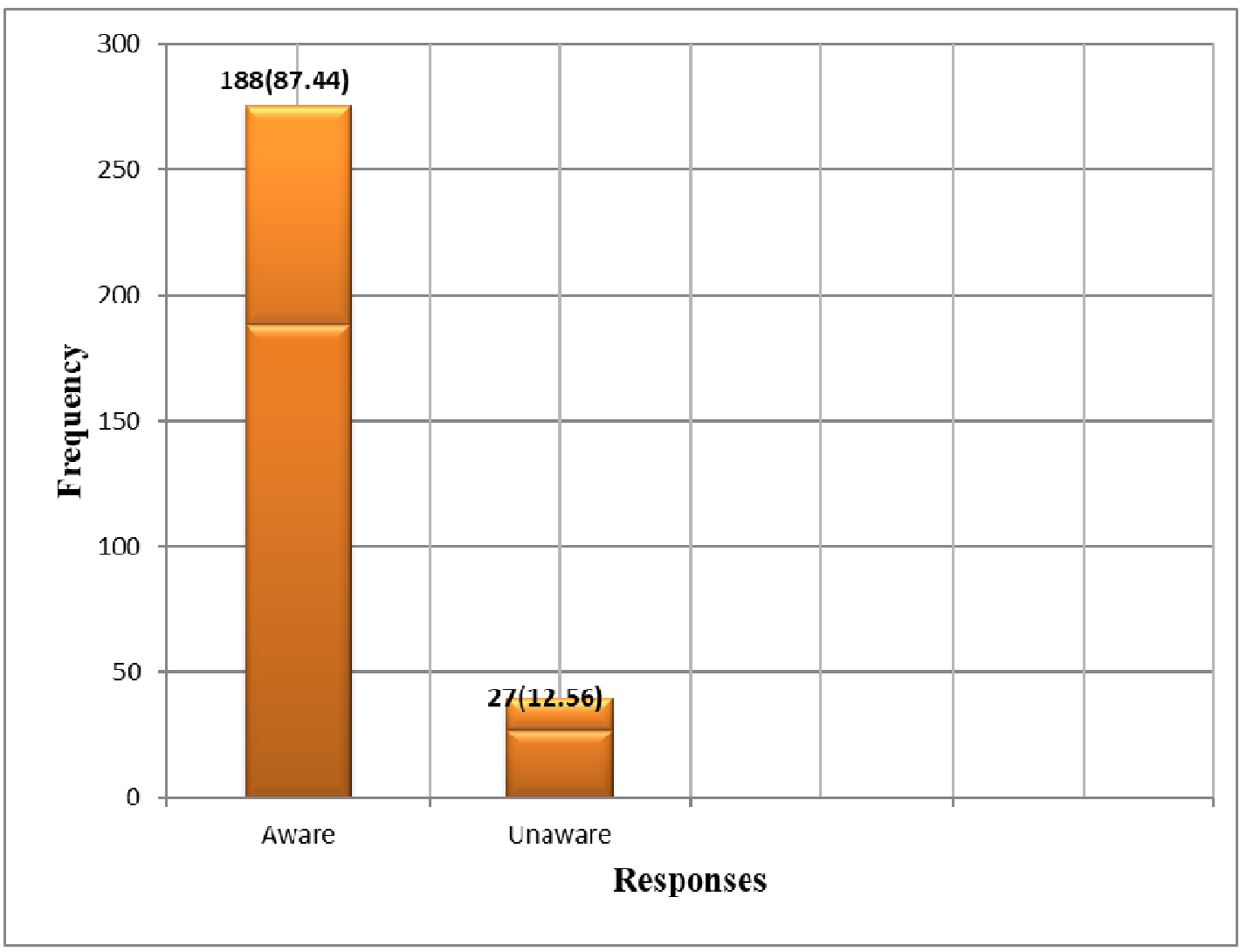

Source: Field data, 2019

Figure 1.1 presents the opinions of the respondents on their awareness of ICT facilities in the library under investigation. Their views indicate that out of the 215 respondents, about 188 representing $87.44 \%$ said that they were aware of the ICT facilities in the library investigated and 27 representing $12.56 \%$ indicated they are unaware of the ICT facilities in the library. This established that a significant number of the respondents were aware of the ICT facilities in the library. This finding revealed that majority of the respondents were aware of the facilities in the library, and they used them to support teaching, learning and research activities and this is in line with Saini, Bhakar, and Singh (2014)'s finding which indicates that majority of students were aware of information and communication technology service (ICTs) in the library.

\subsection{Frequency of use of Information Communication Technology facilities in search of library resources}

The respondents were asked to indicate their frequency of use of information communication technology facilities in search of resources in the library. Table 2 presents the summary of the respondents' views. 
Table 2: Frequency of use of ICT facilities in the VVU Library

\begin{tabular}{lll}
\hline Frequency & Frequency & Percentage (\%) \\
\hline Daily & 75 & $34.88 \%$ \\
Twice in a Week & 51 & $23.72 \%$ \\
Weekly & 39 & $18.14 \%$ \\
Twice in a month & 19 & $8.84 \%$ \\
Monthly & 31 & $14.42 \%$ \\
\hline Total & $\mathbf{2 1 5}$ & $\mathbf{1 0 0}$ \\
\hline
\end{tabular}

Source: Field data, 2019

Table 2 shows how frequent students use ICT facilities in search of library resources. From the table, out of the total of 215 , about 75 making $34.88 \%$ of the respondents indicated that they used the facilities daily, followed by $23.72 \%$ who indicated that they use the library twice in a week, whereas $18.14 \%$ and $14.42 \%$ of the respondents indicated weekly and monthly respectively. The outcome of frequency of use of ICT facilities in the library revealed that majority of $75(34.88 \%)$ of the respondents indicated that they used the facilities in the library on daily basis. The finding of this present study is in line with that of Jagboro (2003) who carried out a similar study on ICT utilization at the Obafemi Awolowo University in Nigeria and established that $22.1 \%$ of the respondents accessed the internet on daily basis, whereas $38.2 \%$ of the respondents accessed the facilities weekly. However, the findings did not confirm the study carried out by Anyira (2011) on the use of internet services in Nigerian private universities. According to Anyira's results, out of the total of 240 respondents, about 100 $(41.7 \%)$ of them said that the internet was slightly accessible to them which disagreed with the current study.

\section{Conclusion}

The introduction of ICT in the service delivery of university libraries did not only impact the performance of information professionals but has also tremendously affected the processes of searching and retrieval of information more easily and quickly. This study discovered that ICT facilities are available in the library investigated. The results revealed that internet, photocopier, and computers are highly patronised than any other facilities in the library, whereas CD-ROMs was the least used facilities. With respect to the frequent of use of these facilities in the library, the study discovered that the users use the facilities frequently to support teaching, learning and research. In contrary, majority of the respondents expressed their dissatisfaction on the insufficient ICT facilities as well as inadequate space in the library as their biggest challenge.

\section{Recommendations}

Based on the findings, the study recommended the following. In the first place, the study discovered that a significant number of the respondents admitted that they were aware of the availability of ICT facilities in the library. It is therefore recommended that management of the library should intensify their awareness creation for all students through library orientations, user education as well as seminars and workshops.

In addition to the awareness creation, management should organize information literacy training for all students irrespective of their level of knowledge in ICT. Finally, the study recommended that management of the library should find a way to acquire more ICT facilities and make them available and accessible to all students. This will go a very long way to enhance teaching, learning and research in the University. In this era of information explosion, it is very important that students who want to pursue higher education must endeavor to acquire ICT skills to enable them do very well in their academic endeavor.

\section{Suggestions for future research}

Based on the findings of this study:

- It is therefore suggested that further studies should be conducted into factors that influence the use of ICT in the Walton Whaley Library of the Valley View University in Ghana.

- Secondly, a study should be conducted into Students' awareness and use of Information Communication Technology in some selected private and public University libraries in Ghana. 


\section{References}

Adedeji, O. A. (2010). The Development of Modern Information and Communications technology in Ibadan: Creative Educational Publications Ltd. p. 58.

Ajuwon, G. A. (2003). Computer and Internet Use by First Year Clinical and Nursing students in a Nigerian Teaching Hospital. BMC Medical Informatics and Decision Making, 3 (10), pp.1472-6947.

Akintunde, S. (2006). The state of ICTs in tertiary institutions in Nigeria. Window on the

universities. In 44th Annual National Conference and Annual General Meeting of the Nigeria Library Association, held at the National Centre for Women Development opposite Central Bank, Central Business District. Abuja.

Anyira, I. E. (2011). Internet Services in Nigerian Private Universities: A Case Study. Library Philosophy and Practice.

Asiamah, S. (2011). Application of Information Communication and Technology: A comparative analysis of male and female Academics in Africa. Retrieved: October 14,2018 fromhttp://www. digital commons. unl.edu/libphil prac/1087?utm_source =digital commons. unl.edu $\%$ 2Flib philpr c\%2F1087\&utm_medium=PDF\&utm_campaign=PDFCoverPages

Chirra, R. \& Madhusudhan, M. (2009). Use of electronic journals by doctoral research scholars of Goa University, India. Library Hi Tech News, 26(10), pp.12-15.

Dike, V. (2005) More than Computers Information Technology in Library and Information Service Education, Ibadan: NALISE, pp.50-59.

Egberongbe, H. S. (2011). The use and impact of Electronic Resources at the University of Lagos. Library Philosophy and Practice. Retrieved from http: //digital com mons.unl. edu/ lib philprac/342.

Ekenna, M.M \& Iyabo, M. (2013) Information Retrieval Skills and Use of Library Electronic Resources by University Undergraduates in Nigeria. Information and Knowledge Management, 3 (9), pp. 6-14.

Ezeani, C.N. (2010). Information Communications Technology: An Overview. Modern Library and Information Science for Information Professionals in Africa. Text Links Publishers, Ibadan. p. 21.

Fu, J.S. (2013). ICT in Education: A critical literature Review and its Implications. International journal of education and development using information and communication technology, 9 (1), pp. 112- 125. Retrieved: December 21, 2018 from http://ijedict.de c.uwi.edu/viewis sue.php?id =34\#Literature_Reviews.

Ifinedo, P. (2006). Acceptance and Continuance Intention of Web-Based Learning. Technologies (WLT) among University Students in a Baltic Country. The Journal of Information Systems in Developing Countries, 23(6), pp. 1-20.

Jagboro, K. O. (2003). A study of Internet usage in Nigeria: A case study of Obafemi Awolowo University, IlleIfe, Nigeria. Retrieved September 15, 2011 from http:/ www. First monday. Organizations/issues 8.2/jagboro/index.html.

Kaur, H \& Mahajan, P. (2014). Information seeking behavior and awareness about the quality of research in this Era of': A survey, International Journal of Information Dissemination and Technology 2, (4), p.262.

Kumar, M. A., \& Reddy, V.P. (2014). Use of E-Journals by Research Scholars in University Libraries in Andhra Pradesh. Library Philosophy and Practice.

Kumarjit, P., \& Lal Vishwakarma, M. (2005). Use of Library Resources in University Libraries by the Students: a survey with special reference to the Assam University, Silchar.

Mohindra, R, \& Kumar, A. (2015). User Satisfaction Regarding Quality of Library Services of AC Joshi Library, Panjab University, Chandigarh" DESIDOC Journal of Library \& Information Technology 35, (1).

Namugera, L. (2014). Users' awareness, perceptions and usage of Makerere library services in the main and selected branch libraries. Qualitative and Quantitative Methods in Libraries (QQML) 3. pp.741-758.

Nkamnebe, E. C., Udem, O. K., \& Nkamnebe, C. B. (2014). Evaluation of the Use of University Library Resources and Services by the Students of Paul University, Awka, Anambra State, Nigeria. Library Philosophy and Practice (e-journal). Paper 1147.

Ojo, R. A., \& Akande, S. O. (2005). Students access, usage and awareness of electronic information resources at the University College Hospital, University of Ibadan, Nigeria. Lagos Journal of Library and Information Science. 3(1), pp.16-24.

Olise, F.P. (2010). Information and communication technologies (ICTs) and sustainable Development in Africa: Mainstreaming the millennium development goals (MDGS) into Nigerian's development agenda. Journal of Social Science, 24(3), pp.155-167.

Omotayo, B.O. (2010). Access, use, and attitudes of academics toward electronic journals: A case study of Obafemi Awolowo University, Ile Ife. Library Philosophy and Practice. Retrieved November 22, 2018, from http://unllib.unl.edu/LPP/omotayo.htm. 
Poudel, R.P. (2010) Access of ICT benefits for underserved rural communities in developing countries: A case study from Nepal. Journal of Asian Scientific Research, 3 (6), pp.587-599.Retrived from http ://www.diplomacy.edu/sites/ default/files/IGC BP2010_2011_Poudel.pdf.

Qutab, S., Bhatti, R \& Ullah, F.S. (2014). Adoption of ICT's For Library Operations and Services: A Comparison of Public and Private University Libraries of Pakistan. Library Philosophy and Practice. Retrieved from http://digitalcommons.unl.edu/libphilprac/1106.

Saini, P.K., Bhakar, R., \& Singh, B. (2014). User satisfaction of the Students of Engineering College: A Case Study of Engineering College Libraries of Jaipur, Rajasthan. International Journal of Emerging Research in Management \& Technology, 3(9), pp. 16-26. Retrieved February 18, 2016, from http ://www.erm t.net/docs/pa pers/Volume_3/9_December2018/V3N9-136.pdf

Wijetunge, P. (2015). Information resources usage by the agriculture undergraduates of University of Peradeniya, Sri Lanka. Annals of Library and Information Studies. 62., pp.77-83 